\title{
Učení a vyučování cizích jazyků a identita
}

\author{
Věra Janíková \\ Masarykova univerzita, Pedagogická fakulta, Katedra německého jazyka a literatury
}

Redakci zasláno 16. 9. 2015 / upravená verze obdržena 27. 1. 2016 /

k uveřejnění přijato 3. 2. 2016

\begin{abstract}
Abstrakt: V posledních přibližně šedesáti letech dochází k dynamickému rozvoji výzkumu procesů učení a vyučování cizích jazyků, s podobnou mírou intenzity jsou rovněž vytvářeny nové teorie, které ozřejmují intencionální a incidentální procesy osvojování jazyků. V obou těchto oblastech se odrážejí nejen nejnovější poznatky relevantních vědních disciplín, ale i požadavky současné společnosti na jazykové vzdělávání. Předložená studie se soustřed'uje na jednu z oblastí, která se stává v poslední době zejména v zahraničí velmi frekventovaným tématem odborného diskurzu v rámci didaktiky cizích jazyků. Touto oblastí jsou komplexní a mnohodimenzionální vztahy mezi jazykem/jazyky a identitou/identitami jedince. V úvodní části příspěvku je podán stručný vhled do konceptualizace identity a nástin vybraných teorií učení a osvojování jazyků, v nichž lze zřetelně identifikovat společné jmenovatele se současným chápáním identity. Poté následuje souhrnná charakteristika vztahů jazyka a identity. Následující část představuje oblasti výuky cizích jazyků, v nichž se konstrukt identity zrcadlí zvláště zřetelně, a v závěru je exemplárně představen dosavadní výzkum zaměřený na zkoumání jazyka a identity v kontextu učení a vyučování cizích jazyků.
\end{abstract}

Klíčová slova: učení a vyučování cizích jazyků, identita, jazyk a identita, teorie, výzkum

0 tom, že identita člověka je tvořena souhrnem mnoha faktorů, z nichž k nejdůležitějším patří jazyk, není třeba polemizovat. Přesvědčivě to dokládají mnohé teoretické i empirické výzkumy zejména filologických a kulturologicky orientovaných věd, v širším kontextu pak i věd dalších, $\mathrm{z}$ nichž na jednom z čelních míst stojí sociologie. Nabízí se tak otázka, zda již není téma identity vyčerpáno a co bylo motivem a cílem pro jeho uchopení v rámci tohoto příspěvku. Po zralé úvaze jsem dospěla k následující odpovědi: I když se v poslední době setkáváme například v rámci sociálních věd s kritickými pohledy na samotný koncept identity i na její zkoumání (např. Fleissner, 2014), ve výzkumu učení a vyučování cizích jazyků je identita zastoupena spíše marginálně a naši pozornost si zasluhuje $\mathrm{z}$ mnoha důvodů. Na tomto místě jmenujme alespoň dva. Jedním ze stěžejních je konstitutivní role jazyka 
při konstrukci a rozvoji identity, přičemž s každým dalším jazykem a jeho kulturou nabývají tyto procesy na nové kvalitě. I v české společnosti dochází $\mathrm{v}$ důsledku narůstající mobility/migrace $\mathrm{k}$ častějšímu a intenzivnějšímu střetávání jedince s jinými jazyky a jejich kulturami, což se odráží i ve výuce cizích jazyků ve školní třídě. A to nejen v tradičním smyslu - učitel, popř. lektor cizího jazyka a jazykově a kulturně homogenní třída. Vlivem zmíněné migrace se totiž mnohdy jedná o model jiný, kdy tento učitel/lektor působí ve tř́dě, která je jazykově a kulturně heterogenní. Dalším důvodem je pak - přinejmenším v rámci evropské jazykové politiky - podpora rozvoje mnohojazyčnosti jedinců mj. tím, že si žák již během povinné školní docházky má osvojit více než jeden cizí jazyk, což je v souvislosti s procesem konstrukce identity uchopováno ve výzkumu učení a vyučování cizích jazyků v zahraničí se značnou razancí (např. Burwitz-Melzer, 2013; Küster, 2010; Norton, 2013). Vychází se přitom z toho, že osvojování mateřského jazyka se významně podílí na konstruování identity, a učení se cizím jazykům (popř. jazyku druhému), k čemuž dochází zpravidla v pozdějším věku, znamená získávání pohledu na svět kolem nás z jiné perspektivy a na rozvoj identity má značný vliv. A právě tento aspekt rezonuje s jedním z hlavních cílů současné výuky cizích jazyků, k nimž patří umožnit učícím se jedincům vyrovnávat se s jinakostí, reflektovat a ve výukových situacích „prožít“ jazykové a kulturní rozdíly i shody. Ve výuce je sice identita latentně přítomna vždy, ale explicitní zájem o ni jako o konkrétní obsah výuky a předmět výzkumu zaznamenáváme až v posledních několika letech. Tyto důvody se staly impulsem k tvorbě předložené studie, jejímž cílem je se vší vědeckou pokorou ve smyslu neskrývaného hledání vnést toto téma do odborného diskurzu české didaktiky cizích jazyků v jejím propojení s teoretickým i empirickým výzkumem, v němž doposud uchopeno nebylo.

\section{K pojetí identity}

Záměrem této kapitoly je uchopit identitu s ohledem na její usouvztažnění s výzkumným polem učení a vyučování cizích jazyků. Za poctivé považuji předeslat, že téma identity a její povahy je velmi rozsáhlé, což neumožňuje v rámci jedné studie předložit vyčerpávající výklad. Proto je hlavní pozornost věnována současnému pojetí identity, které je v úvodní části ukotveno ve stručném náhledu na stěžejní proudy a představitele, kteří se na vývoji pojmu identita podíleli. 
Obecně patří identita mezi fenomény, které je díky jejich komplexnosti obtížné nejen uchopit, ale i jednoznačně vymezit, o což se nicméně snaží vědecký diskurz na poli vývojově- a sociálněpsychologickém (např. Výrost \& Slaměník, 2008), sociologickém, ale i (sociálně) pedagogickém (např. Švaříček, 2007) či, v prŕípadě jazyka a identity pak zejména, sociokulturním a sociolingvistickém (např. Werlen, 2002) či pragmalingvistickém (např. Aguado, 2013).

Nejdříve se identita objevuje v psychologickém, resp. psychoanalytickém diskurzu a jako první s ní cíleně pracuje Erikson (1996), který rozpracovává pro další vývoj zásadní teorii, tzv. ego teorii identity. Autor v ní vychází z duálního charakteru identity a rozlišuje ego identitu ve smyslu psychologického mechanismu umožňujícího udržet vnitřní kontinuitu a stejnost v čase a self identitu jako sebevnímání, což považuje za stěžejní. Identita v jeho pojetí zahrnuje vnitřní procesy jedince (individuální struktury) a procesy ve struktuře sdílených kulturních hodnot, přičemž za rozhodující pro formování identity považuje vrozené charakteristiky jedince. Erikson (1996) zároveň podtrhuje vývojový aspekt procesu formování identity s důrazem kladeným na dobu pozdní adolescence (srov. např. Macek, 2003), identitě obecně připisuje nejen stálost, ale současně i proměnlivost či pomíjivost.

Poměrně brzy však dochází ke kritice Eriksonovy teorie, jíž je vytýkána zejména př́lišná akcentace vrozenosti, zásadní význam pro formování identity začíná být připisován sociálnímu prostředí a sociální interakci s druhými lidmi. Dochází k proměně psychologických paradigmat a nástupu paradigmatu sociálního, v němž je již za jeden z jejích hlavních aspektů vnímán jazyk. Zároveň se zde setkáváme $\mathrm{s}$ dichotomním členěním identity, v němž je rozlišována na jedné straně identita osobní (personální/individuální) jako názor na schopnosti, dovednosti a vlastnosti jedince, a na druhé straně identita sociální (popř. společenská/kolektivní), která se vztahuje k členství v určité sociální skupině, projevuje se emoční angažovaností a hodnotovým významem spojeným s tímto členstvím (srov. Výrost \& Slaměník, 2008, s. 47). Toto přehodnocení se do značné míry projevuje již u Eriksonova pokračovatele, kterým je Marcia, jenž považuje za dvě významné složky identity krizi a závazek, přičemž krizí je míněno hledání a rozhodování o závazku identity a závazkem docílení pevných a stálých hodnot a přesvědčení v různých sférách života.

K vymezení identity ze sociologicko-psychologického pohledu přistupuje symbolicky interakcionalistická teorie identity (např. Mead, 1968), v níž 
je "Já" (self) definováno jako hierarchická struktura internalizovaných rolí, které jedinec během svého života v různých situacích „hraje“ a jak se v nich chová, přičemž rolí ${ }^{1}$ je míněna právě identita (např. role či identita matky, učitele atd.). Postupně tak vzniká koncept tzv. vícenásobné identity (multiple Identität, srov. např. Kresic, 2006, s. 81). Identita a chování jedince jsou zde nahlíženy ve vzájemně podmíněném vztahu: identita ovlivňuje chování a chování ovlivňuje identitu, a to při užívání jakéhokoli jazyka. Těžiště Meadovy teorie identity tvoří tedy představa o tom, že naše „Já“ je konstituováno v sociální interakci a hlavním médiem je přitom jazyk, který se označuje jako prostředek „,kooperace, která se uskutečňuje pomocí signálů a gest“ (Mead, 1968, s. 44). Zdůrazňuje tak vztah mezi užíváním jazyka a změnou identity (resp. jedné z identit; Mead, 1968, s. 184). I když Mead nezohledňuje vnitřní strukturu jazykových systémů ani pragmalingvistiku (zejména v oblasti mluvních aktů), skrývá jeho přístup k identitě četné jazykově teoretické a jazykově filozofické implikace, které lze nalézt v řadě teorií učení/osvojování (cizích) jazyků, o nichž se zmíníme níže.

V této souvislosti se jako relevantní jeví i etnolingvistická teorie identity, která považuje za stimulus pro získání pozitivní sociální identity zvýšené sebevědomí při užívání jazyka dominantnější skupiny a explicitně hovoří o kulturní a jazykové identitě (srov. Výrost \& Slaměník, 2008, s. 48).

Ve výrazném protikladu k počátečnímu vnímání identity jako stabilního rysu osobnosti jedince (viz Erikson, 1996) stojí pojetí konstruktivistické, jež identitu nepovažuje za vnitřní vlastnost, ale chápe ji jako konstrukci jednání, čímž podtrhuje její dynamický charakter. Na toto pojetí navazují postmoderní úvahy, v nichž se mimo jiné silně odrážejí pochybnosti o možnosti dojít ke konsensu v otázkách vymezení identity. Tyto úvahy jsou determinovány nejen novými vědeckými poznatky, ale i vývojem společnosti a nových či měnících se podmínek a faktorů ovlivňujících konstituování a rozvoj identity. Společně s výše uvedenými pojetími se poté stávají východiskem pro její současné chápání.

\subsection{Současné pojetí identity}

Pro současné vnímání identity, resp. chápání obsahu identity, je charakteristická pluralita pohledů v interdisciplinárním rámci s respektováním toho,

1 Tento aspekt se může vzhledem $\mathrm{k}$ identitě cíleně uchopit $\mathrm{v}$ jedné $\mathrm{z}$ výukových metod, která je vcelku běžně používána ve výuce cizích jazyků - v tzv. hraní rolí. 
že jedinec - příslušník moderní společnosti - je vystaven velkému množství interakcí, v nichž na jeho identitu působí velké množství faktorů. Identita je pojímána v celé své mnohovrstevnatosti a mnohoaspektovosti a v návaznosti na koncept internalizovaných rolí jedince (viz kap. 2) hovoří mnozí odborníci ne o jedné, ale o více identitách, které jsou utvářeny vztahy a jejich proměnlivou dynamikou (Hrdá \& Šíp, 2011, s. 442). K nejdůležitějším rysům současného chápání identity patří zejména:

- důraz na dílčí (situační) souvislosti a na úzkou provázanost s kulturou a historií;

- zkoumání nejen samotného jedince, ale i vnějšího světa, kterým je tento jedinec obklopen;

- multiperspektivnost ve smyslu respektování různých způsobů a úhlů náhledu na dění a místo aktérů v něm;

- důraz na prolínání a splývání identit v síti rozmanitých vztahů k jiným lidem (např. identita kulturní, národní či etnická);

- vícenásobnost (identitu tvoří řada rolí, které se v každodenním životě flexibilně stř́idají a mění);

- dynamika (identita se neustále vyvíjí/přetváří, představuje hledání plurality měnících se významů);

- důraz na hodnoty (identita je určována hodnotami, jejich interpretací; stejně jako $\mathrm{u}$ hodnot, tak i $\mathrm{v}$ přístupu $\mathrm{k}$ identitě během života převládá nikoliv neměnnost, ale dynamika a kontinuální změny);

- praktičnost (při konstruování identity převládá užitečnost a praktické zájmy, v popředí je praktické poznání; ${ }^{2}$ stejně tak platí, že identita je ověřována praxí a ne teoriemi);

2 V této souvislosti je třeba zmínit teorii diskurzů Foucaulta (např. 1987), o niž se opírá zejména sociologie vzhledem k otázkám formování sociálních identit. Tato teorie ozřejmuje vzájemnou závislost společnosti a jazyka. Diskurz pro Foucaulta znamená propojení lingvistického systému reprezentace se způsobem produkce vědění (epistemologická rovina), je tedy ukotven jak v jazyce, tak ve vědění i diskurzivních praktikách. Při formování sociálních identit hovoří o různých typech těchto praktik, přičemž k „důležitějším“ řadí ty, jež subjekty učí provádět ty praktiky, které jsou pro ně subjektivně zvláště významné vzhledem k určité společnosti (kolektivitě), jako je například mluvení jejím jazykem. 
- důraz na jazyk (jazyk je pro identitu konstitutivní, nahlíží na realitu z určité perspektivy - „očima“ struktury a zejména pragmatiky konkrétního jazyka (jazyková identita) a jeho kultury (srov. Bačová, 1997, s. 215-228).

Ačkoli se ve výše uvedeném přehledu nejcharakterističtějších rysů současných přístupů $\mathrm{k}$ identitě nachází jazyk $\mathrm{v}$ jeho závěru, neznamená to, že v nich sehrává méně důležitou roli. Nebot' jazyk - v neoddělitelném spojení s kulturou - je zde ve snahách o komplexnější vnímání identity úzce spojen s významně narůstající individuální i společenskou mnohojazyčností a interkulturalitou, popř. transkulturalitou jdoucími mimo jiné ruku v ruce se zvyšující se migrací v rámci etnických, kulturních i jazykových hranic (srov. MüllerHartmann, 2013, s. 208), která je charakteristická pro soudobou společnost. (I) tyto skutečnosti vedou $\mathrm{k}$ tomu, že v současnosti zaznamenáváme poměrně silný tlak na naši identitu ve smyslu „hledání Já“ (Říčan, 1999) v psychologickém, sociálněpsychologickém a sociologickém pojetí identity.

Shrneme-li výše nastíněné krátké pojednání, můžeme vzhledem k identitě a jejímu pojímání vyslovit následující shrnutí: $V$ obecné rovině je možné chápat identitu jedince jako amalgám osobních (individuálních) a sociálních (kolektivních) aspektů. Identitu tak lze označit jako hluboký pocit vlastní totožnosti založený na prožívání vlastní komunity, tedy jakým člověkem jsem a čím se liším od druhých, jinými slovy jako „prožívání toho, čím jedinec je (vlastní autenticity, jedinečnosti a konzistentnosti v čase a prostoru), bud' jako individuum, nebo jako člen lidských společenstev“ (Bačová, 1997, s. 211). Pro sledování identity jedince se jeví jako esenciální náhled na základě jeho biologických a genetických dispozic, fenotypických určení a psychologických nastavení. Jedinec však přichází na svět v různém sociálním, politickém, ekonomickém a kulturním prostředí $\mathrm{v}$ rámci různých společenství a vstupuje tak do nejrůznějších vztahů a kontaktů, což je pro poznání identity zásadní. Obsahem identity člověka se tak stává systém vztahů, který profiluje jeho osobnost, myšlení a formuje jeho vědomí. Identita člověka spočívá $\mathrm{v}$ těchto vztazích $\mathrm{k}$ okolí, které se mohou v různých životních obdobích pod vlivem vnitřních i vnějších faktorů měnit, což identitě propůjčuje jistý stupeň nestability a činí z ní fenomén, který se rozvíjí celoživotně. Identita označuje také ztotožnění jedince se svými životními rolemi, souhrn sociálních rolí. Vzhledem k tomu, že jedinec má tolik sociálních „já“, kolik má skupin, se kterými je schopný se identifikovat, přiklání se mnozí odborníci k tomu, že jedinec má identit více. Ty pak např. Jandourek (2001) označuje jako „identity parciální". Identita se vždy vyvíjí v konkrétním sociálním a kulturním 
kontextu. Jako fenomén individuální je vnímána jako sebeuvědomění jedince a vztahuje se tak k vnitřní dimenzi jejího pojetí, resp. vědomí jedince, nebot' „identita je záležitostí vědomí, tedy reflektivního uchopení nevědomého sebeobrazu“ (Assmann, 2001, s. 115), zahrnuje hodnoty, kterým člověk věří, a může na nich založit smysl svého života nebo osobní ideologii. Za jeden ze zásadních aspektů identity v rámci její konstrukce i ko-konstrukce je považován jazyk.

Vzhledem k zaměření tohoto příspěvku bude v následující kapitole pojednáno o vzájemném vztahu mezi př́stupy k identitě a relevantními vybranými teoriemi intencionálních a incidentálních procesů osvojování (cizích) jazyků. Toto pojednání zároveň uvádí následující kapitolu, v níž je nastíněn vztah jazyka a identity.

\section{Teorie učení (osvojování) (cizích) jazyků a identita}

Podobně jako u přístupů $\mathrm{k}$ identitě zaznamenáváme i v oblasti teorií učení (osvojování) (cizích) jazyků různé teorie a hypotézy, které reflektují současný stav poznání a zároveň akcentují určité aspekty těchto procesů. V souvislosti s dichotomním vnímáním identity ve smyslu identity osobní (individuální) a sociální (kolektivní), s přihlédnutím k jejich vzájemnému prolínání, je i v této oblasti možné zaznamenat určité paralely, které na tomto místě ukotvujeme ve světle současného náhledu na procesy učení (osvojování) (cizích) jazyků.

V současnosti se v oblasti teorií osvojování (cizích) jazyků ve stále rostoucí míře začínají prosazovat teorie, v nichž jsou zdůrazňovány sociálněinteraktivní aspekty a akcentovány individuální předpoklady a podmínky jedince v rámci procesů osvojování jazyků. Podobně tomu je u teorií identity, jako je např́íklad teorie sociální identity, s diskurzem jako zásadním aspektem pro udržování sociálních interakcí nebo konstrukci osobnosti. V dané souvislosti exemplárně uvádíme tři vybrané teorie osvojování jazyka, v jejichž následném stručném popisu můžeme spatřit mnohé paralely mezi osvojováním jazyků a utvářením, resp. rozvojem identity. Jedná se o sociokulturní teorii (sociocultural theory, SCT), interakční hypotézu (interaction hypothesis) a tzv. hypotézu jedince (Einzelgänger-Hypothese).

Sociokulturní prístup se etabloval v souvislosti s osvojováním druhého jazyka. Opírá se o dílo sovětského psychologa Vygotského, na nějž navázal v oblasti učení se cizím jazykům v polovině osmdesátých let minulého století zejména 
Lantolf a Thorne (2006; viz rovněž Aguado, 2010, s. 816-822). Vygotskij (2004) vyjadřuje přesvědčení, že lidé při vytváření svého vztahu vůči sobě samým, k sobě navzájem i $\mathrm{k}$ vnějšímu světu, využívají různých kulturně podmíněných zprostředkovacích nástrojů, resp. symbolických prostředků, z nichž k nejdůležitějším a stále přítomným patř́ jazyk (Lantolf \& Thorne, 2006, s. 205), který se stává i „nástrojem myšlení“ (Schoormann \& Schlak, 2012, s. 178).

Tato teorie hovoří o tom, že osvojování jazyků není závislé pouze na vnitřních procesech a individuálních předpokladech (determinantách) jedinců, ale ve velké míře také na faktorech vnějších, k nimž patří faktory sociokulturní. Zde tak nalézáme jednu z významných paralel mezi osvojováním (učením) jazyků a identitou, nebot' mnohočetný soubor vnitřních i vnějších faktorů má vliv i na utváření a rozvoj identity jedince. Sociokulturní teorie dále vnímá osvojování jazyků v obecné rovině jako holistický a primárně sociální proces (Aguado, 2010, s. 821), podobně je chápána identita v současném pojetí.

Sociokulturní teorie osvojování bývá často dávána do souvislosti s tzv. interakční hypotézou ${ }^{3}$ (Long, 1983). Tato hypotéza říká, že sociální interakce, ve které dochází k vyjednávání významu, usnadňuje osvojování jazyků, protože modifikace, $\mathrm{k}$ nimž v rámci této interakce dochází, poskytují jedincům (v rámci institucionálního učení se jazykům žákům) tzv. srozumitelný vstup ${ }^{4}$ který potřebují. Účinnost srozumitelného vstupu se podle Longa významně zvyšuje, když se objevuje komunikační problém a jedinci potřebují vyjednat význam. V sociálně a kulturně zasazené interakci - at’ se jedná o intencionální nebo incidentální osvojování jazyků - jedinec mobilizuje své existující kulturně vázané pohledy na svět a využívá je při procesu vyjednávání významu.

Toto vyjednávání akcentuje v obecné rovině sociokulturní či interakční přístup. První z nich se však více zaměřuje na to, co se při něm v procesu interakce odehrává, zatímco druhý - interakční hypotéza - zdůrazňuje vnitřní mentální procesy, jež interakce aktivuje. Interakce mezi jedinci je součástí procesů osvojování jazyků (Swain, 2005), stejně tak jako je pomocí interakce vytvářena vlastní identita jedince. $\mathrm{V}$ obou teoriích nalézáme úzkou provázanost

3 Vygotskij zaměřil svoji pozornost jednak k interpersonální, jednak i intrapersonální interakci. Zatímco se druhá jmenovaná zabývá konstruováním struktur v rozhovoru (v mluvené či psané řeči) sama se sebou, první zmiňovaná vyzdvihuje právě roli interakce jedince s jeho okolím (Saville-Troike, 2006, s. 112-116).

4 Jedním z východisek interakční teorie je Krashenova teorie vstupu (Krashen, 1985). 
mezi jedincem a skupinou, podobně jako $\mathrm{v}$ teoriích identity. Tento aspekt propojuje psychologický pohled na identitu s procesy osvojování jazyků, nebot' v obou případech platí, že „psychologické procesy se zřetelně projevují v kolektivním chování, ve spolupráci s jinými lidmi, a teprve potom jsou internalizovány jako majetek konkrétního jedince" (Stetsenko \& Arievitch, 1997, s. 161). A tím jsou jak znalosti jazyků jedince, tak i jeho osobní identita.

Ve vztahu k osvojování cizích jazyků v edukační praxi, tedy jejich učení pod vedením pedagoga, je třeba zmínit fakt, že sociokulturní, resp. sociokulturně-interakcionalistický př́ístup je v obecné rovině i „předmětem zájmu pedagogiky zaměřené na pedagogickou interakci (interakce a komunikace ve tř́dě ve smyslu vzájemného působení učitele a žáků)" (Tůma, 2014, s. 181). Jedním ze stěžejních východisek tohoto přístupu je mediace. Nebot’ stejně jako každá jiná duševní aktivita je mediováno také učení ${ }^{5}$ ( $v$ našem případě učení se cizím jazykům), at' pomocí sociální interakce nebo kulturně konstruovaných artefaktů, které představují do jisté míry „materializované“ výsledky sociální interakce (Schoormann \& Schlak, 2012, s. 178). Na tomto místě vstupuje do hry specifický koncept profesionální identity, konkrétně profesionální identity učitele, o níž bude pojednáno níže.

Vzhledem ke vztahům mezi teoriemi osvojování jazyků a identitou se nabízí rovněž zmínka o tzv. hypotéze jedince (Riemer, 1997), která byla ověřována zejména v souvislosti s výzkumem motivace při učení se cizím jazykům. Tato hypotéza je spojena s konceptem individuálních rozdílů v předpokladech jedince pro učení se cizím jazykům, jimiž je míněna řada navzájem propojených proměnných, které při tomto procesu implikují rozdílné přístupy k učení. V komplexu těchto proměnných ${ }^{6}$ je třeba vzhledem ke konstruktu identity mít na paměti mj. kulturní, popř. sociokulturní dimenzi, nebot' každá kultura, společnost či náboženství může vnímat identitu a individualitu jedince různě (srov. Hufeisen, 2013, s. 82), což se poté může odrazit i v samotných procesech učení se jazykům. Současně s tím úzce souvisí i individuální repertoár jazyků, který daný jedinec na různých úrovních ovládá a v různých komunikačních situacích s různými motivy a cíli užívá, čímž si zároveň rozvíjí svoji identitu, resp. identity v širším jazykovém a kulturním spektru.

Více viz Tůma (2014).

Z Zejména v souvislosti s osobní identitou zdůrazňuje např. Skehan (1998) tzv. osobnostní faktory, které mohou mít významný vliv na učení/osvojování (cizích) jazyků, k nimž řadí vedle např. etnocentrismu, autoritářství, osobní angažovanosti, vytrvalosti, introverze nebo extroverze, rodinného zázemí a kulturního prostředí či dřívějších zkušeností i jazykovou identitu, kterou označuje jako language ego. 


\section{$3 \quad$ Jazyk a identita}

Jazyk představuje v konstruktu identity velmi důležité, ne-li zásadní místo. Již sám o sobě je symbolem a pro lidské společenství představuje strukturu symbolických hodnot. A jsou to právě jazyky (národní či etnické), které jsou považovány za základ kulturních odlišností mezi lidskými skupinami. Zdůraznit je třeba také fakt, „,̌̌e z hlediska společnosti funguje jazyk jako svého druhu kontinuum, které je v průběhu staletí jejím nejcharakterističtějším znakem“ (Furdal, 2004, s. 242). Jako společenský fenomén má dvě základní funkce: komunikační a identifikační, které jsou v konstruktu identity inherentní a navzájem se velmi úzce prolínají. Jazyk je pro identitu konstitutivní - bez jazyka určité skupiny, s níž se jedinec chce nebo musí identifikovat (i kdyby to bylo proti jeho vlastní vůli), by formování či rozvoj identity nebyly možné. Podle Bühlera (1934, cit. podle Meißnera, 2013, s. 195) působí jazyk mj. jako určitý „signál“ (Když mluvím, ukazuji ti, kdo jsem.) a zároveň jako „apel“ (Říkám ti pomocí uspořádání své řeči, jak tě nyní a zde hodnotím, ty mně ukazuješ, za koho mne považuješ.). Jazyk je médium pro konstrukci identity (Blell, 2013, s. 30), ${ }^{7}$ a to jazyk mateřský i osvojené jazyky další. Prostřednictvím prvního/mateřského jazyka je jedinci umožněno pochopit své „Já“ a artikulovat jej (osobní identita), stejně jako si uvědomovat svoji př́islušnost k rodině i společenství (sociální identita). Pomocí prvního jazyka, popř. jazyků si zpravidla vštěpujeme religiózní i kulturní hodnoty (kulturní identita). Pro mnoho jedinců je konstrukce identity monolingvní, přičemž:

první jazyk se stává nejen jistým ostrovem jistoty, který vytváří a posiluje vztahy, ale zároveň i „vězením“, které u člověka vytváŕí tzv. monolingvní světový názor, jež může vést $\mathrm{k}$ tomu, že jakákoliv odchylka od vlastní jazykové normy je vnímána jako něco cizího a ohrožujícího. (Krumm, 2013, s. 119)

Mezi námi jsou tedy lidé, kteří prostřednictvím uvědomělého používání dalších jazyků hledají cestu k rozšíření své identity, ale také ti, kteří mají zábrany učit se dalšímu jazyku a používat jej, nebot' ten pro ně představuje ohrožení jejich identity, která je velmi úzce spojena právě s jazykem (napřr. Kresic, 2006).

Význam jazyka ve smyslu úrovně jeho ovládání podtrhuje např. Krappmann (1993), který připisuje zásadní význam stupni tzv. „virtuozity“ při zacházení

Blellová (2013, s. 31) připomíná, že konstruování identity v rámci výuky cizích jazyků se více či méně uvědoměle - děje zejména v souvislosti s rozvojem kompetencí v oblasti řečové recepce i produkce, v oblasti interkulturního učení i práce s literárním textem. 
s jazykem v procesu rozvoje identity. Čím lépe (virtuózněji) jedinec s jazykem zachází, tedy jej ovládá a správně chápe význam jazykového projevu, tím intenzivněji probíhají procesy sebeutváření osobnosti v rámci rozvoje vlastní identity. V tomto kontextu hovoří Königs (2013, s. 13) také o tzv. estetické kvalitě jazyka, čímž míní subjektivně estetické vnímání vlastního úspěšného užívání konkrétního jazyka, případně jazyků. Př́ijemné pocity, ocenění či přijetí partnerem v komunikaci vyplývající z dobré znalosti jazyka (Königs tuto skutečnost označuje jako estetické působení jazyka mateřského, druhého i cizího) může u jedince pozitivně ovlivnit rozvoj identity.

Z toho vyplývá přinejmenším jedno: Identita se vyvíjí ne tím, že jedinec hovoří nějakým jazykem, který je popsatelný pomocí určitých lingvistických kategorií nebo kritérií. Nerozvíjíme tedy svoji identitu proto, že hovoříme nějakým jazykem $\mathrm{s}$ jeho charakteristickými znaky (např. $\mathrm{v}$ němčině větný rámec nebo slovesa s odlučitelnou předponou), ale protože nás tento jazyk je schopen dostat do situace, kdy dochází k interakci s ostatními, při níž zjišt’ujeme, jaká očekávání na nás má daná společnost a jaký obraz sebe sama o sobě máme, a protože s jeho pomocí můžeme uspokojovat své potřeby a touhy (srov. Königs, 2013, s. 19). Jazyk tedy nepodporuje identitu ve smyslu abstraktního a systémového útvaru, ale ve smyslu komunikačního prostředku v jeho užívání. ${ }^{8}$

Zejména vícejazyční jedinci si zpravidla mnohem více uvědomují, jakou roli pro ně jazyk/y hraje/hrají. Četné studie (např. Krumm, 2003) ukazují, jak jsou určité jazyky v jejich mysli často hluboce zakořeněny, s jakou emoční intenzitou je obsazeno vlastnictví jazyků a jak bolestivý může být poznatek, že určitá pravidla při užívání jazyka díky změněným rámcovým podmínkám již neplatí. To se může odrazit i v procesu rozvoje identity, který se poté začíná ubírat jiným směrem, než jakým by se ubírat měl či mohl.

Hovoříme-li o vztahu jazyka a identity, nemůžeme opomenout lingvistiku jako vědní disciplínu zkoumající přirozený jazyk. Ta v rámci svých četných dílčích disciplín více či méně reflektuje různé aspekty interakční a komunikační funkce jazykového projevu se zřetelem ke kulturnímu kontextu. Königs $(2013$, s. 12) v této souvislosti zdůrazňuje význam myšlenek Meada, které

Jsme si plně vědomi toho, že vztahy mezi identitou a cizím jazykem jako nástrojem a reprezentantem určité kultury jsou mnohem složitější, na což poukazují např. Hofstede a Hofstede (2007) a což se zřetelně projevuje v konceptech interkulturní komunikace, resp. v kulturních specifikách komunikace (např. Průcha, 2010). 
byly nastíněny již výše v tomto textu (kap. 2) a které se staly v rámci přístupů $\mathrm{k}$ identitě v obecnější rovině významným impulsem pro uchopení tohoto konstruktu v lingvistice. Pro zkoumání vztahů mezi jazykem a identitou sehrávají kromě lingvistických disciplín zkoumajících jazykové podsystémy (fonetika, fonologie, lexikologie, syntax, sémantika aj.) a tzv. tradičních lingvistik (např. historická lingvistika, sociolingvistika, pragmalingvistika, lingvistická genealogie a typologie či psycholingvistika) zásadní roli lingvistiky chápané jako širší vědní disciplíny. Jedná se zejména o (1) kognitivní lingvistiku, která zkoumá jazyk jako mentální nástroj, pomocí něhož jedinec poznává, kategorizuje a interpretuje svět; jazyk považuje za součást lidské kognice; (2) lingvistiku jako součást sémiotiky, která chápe jazyk jako soubor jazykových znaků ve smyslu vztahů mezi myšlenkami (mentálními koncepty), jejich formálním vyjádřením a vnějším okolím; tyto vztahy umožňují komunikaci, a to jak verbální, tak i neverbální; (3) lingvistiku jako součást filologie, jež zkoumá jazyk v jeho vztahu k člověku, jako např. vzájemné vlivy národa a jazyka, kultury, historie, společnosti či literatury (více viz např. Černý, 1998; Čermák, 2001).

V neposlední řadě je třeba se alespoň krátce dotknout filozofie jazyka, jež byla zmíněna v kapitole $2 \mathrm{v}$ souvislosti s jazykově filozofickou rovinou vnímání vztahu jazyka a identity. Stěžejní je v daném př́ípadě Wittgensteinova (1998) pozdější fáze zkoumání, v níž chtěl pomocí termínu jazyková hra podtrhnout různorodost aktivit člověka, které se opírají o jazyk. Dochází k následujícímu závěru: Určitému znaku dává „život“ teprve jeho použití a při něm poté tento znak získává svůj význam; existuje tedy tolik jazykových stylů, kolik je forem života. Četnost tzv. jazykových her se zvyšuje díky mnoha možnostem jejich využití v různých (sub)kulturách a společnostech. U Wittgensteina tak můžeme pozorovat úzké spojení mezi jazykem ve smyslu účasti na jazykové hře či řečovém stylu v rámci specifické životní formy/role, ${ }^{9}$ kterou můžeme vnímat jak sociokulturní identitu (Kresic, 2006, s. 32-33).

Složitý a spletitý vztah identity a jazyka se odráží i v oblasti výuky cizích jazyků. V následujícím textu nabízíme několik vybraných pohledů na tuto problematiku.

Zde nacházíme paralely se symbolickyinterakcionalistickou teorií identity (Mead, 1968), s konceptem vícenásobné identity a internalizovaných rolí, které jedinec během svého života v různých situacích „hraje“, jak se v nich chová (i jazykově). 


\section{$4 \quad$ Výuka cizích jazyků a identita}

Výuku cizích jazyků považujeme za situaci, v níž se výrazně prolíná identita osobní (žák, učitel) s identitou sociální či kolektivní (v užším slova smyslu společenství školní třídy, v širším smyslu např. mimoškolní - extrolingvní používání jazyka v interakci s rodilým mluvčím daného jazyka). Na identitu zde tedy nahlížíme v obou jejích rovinách s respektováním jejího dynamického a mnohovrstevnatého charakteru.

Zastavme se na tomto místě u vzájemné interakce mezi subjektem řídícím vyučování (učitel) a subjektem řízeným (žák). V obou případech se jedná o identitu v její podstatě, tedy o uvědomění si vlastní odlišnosti „k těm druhým“ a jejím utvářením v interakci s okolím, které je obklopuje. $V$ našem případě se jedná o specifickou interakci mezi žákem a učitelem cizích jazyků, přičemž oba si do této výuky přinášejí svou/své osobní i sociální identitu/identity a dále ji/je rozvíjejí. U učitele cizích jazyků se jedná například o jeho identitu profesní (k profesní identitě učitelů např. Švaříček, 2007), v jejímž rámci jedná ve smyslu utváření výsledné podoby výuky cizích jazyků s tím, že ta cíleně podporuje zacházení s mnohonásobnými identitami žáka ve výuce a rozvíjí je. Klíčovým předpokladem je učitelovo vnímání sebe sama a své vlastní (profesní) identity (srov. Lukas \& Švaříček, 2007, s. 8), tedy vlastního přesvědčení, jak by taková výuka měla vypadat.

Toto jednání učitele cizích jazyků je ovlivněno z pohledu identity řadou specifických faktorů, z nichž uvádíme dva a to (1) provázanost mezi osobní a sociální identitou v rámci učitelovy profesní identity a (2) vnější faktory formující jeho profesní identitu. Velmi úzkou provázanost mezi osobní a sociální (kolektivní) identitou nalézáme v př́ípadě, kdy nová kolektivní identita je včleňována do vlastní osobní identity (srov. Mlynář, 2015, s. 259). Tento proces můžeme v kontextu výuky cizích jazyků pozorovat $v$ případě, že se jedná o učitele-nerodilého mluvčího jím vyučovaného jazyka (např. český učitel italštiny v české škole), který zprostředkovává žákům nejen nový jazyk, ale i novou kulturu, a do jisté míry se identifikuje s tímto jazykem i kulturou a pro žáky může představovat reprezentanta této kultury. K mnohem těsnější provázanosti mezi oběma typy identit však dochází v př́́padě, kdy učitel zprostředkovává výuku jazyka své kultury (např. jako lektor anglického původu ve výuce angličtiny v české škole). Z hlediska vnějších faktorů působících zejména na profesní identitu učitele cizích jazyků se jedná například o konkrétní politický i společensko-kulturní kontext a v něm „ústy“ 
vládních institucí formulovaná jazyková politika nebo jazykové vzdělávání. Stejně tak se může jednat o v tomto kontextu preferovaný metodicko-didaktický koncept výuky cizích jazyků ve vysokoškolské přípravě budoucích učitelů cizích jazyků apod. Ne vždy se totiž učitel ve svém vnitřním přesvědčení může s deklarovanými „doporučeními“ zcela identifikovat. $V$ obou případech tak může docházet $\mathrm{k}$ jisté disharmonii jak v rámci osobní a sociální identity, tak i v jejich vzájemném vztahu (srov. Medgyes, 1994).

O vztahu identity a procesů učení a vyučování cizích jazyků se v posledních několika letech začínají vést odborné diskuse se zvýšenou intenzitou (viz např. Schmelter, 2013). K výsledkům zásadního charakteru patří to, že zainteresovaní odborníci (společně s didaktiky cizích jazyků jsou to i mnozí lingvisté či filozofové, kteří se zabývají filozofií jazyka) se sjednotili v tom, že je třeba navzájem neoddělitelné spojení jazyka a identity při zkoumání těchto procesů ve větší míře akcentovat a výsledky implementovat do didaktiky cizích jazyků jako profesní vědy pro učitele cizích jazyků (Burwitz-Melzer, 2013, s. 39). Zkoumány musí být oba subjekty, a to jak učitel, tak i žák, a zohledňovat je třeba řadu aspektů vyplývajících z jedinečnosti a specifičnosti procesů učení a vyučování cizím jazykům, různorodosti pojetí identity, její různé typy (např. osobní/individuální, kolektivní/sociální, kulturní či jazyková $^{10}$ ), stejně jako její dynamičnost a mnohonásobnost. Následně uvedeme exemplárně čtyři oblasti výuky cizích jazyků, v nichž se konstrukt identity zrcadlí zvláště intenzivně. Jedná se o (1) interkulturní komunikační kompetenci coby hlavního cíle současné cizojazyčné výuky, (2) motivaci ve vztahu k učení se jazykům, (3) koncept výuky zaměřené na žáka a (4) rozvoj individuální mnohojazyčnosti jako jednoho z významných dílčích cílů současné cizojazyčné výuky.

\section{ad 1) Interkulturní komunikační kompetence a identita}

V postkomunikačním období dochází k jistým změnám při stanovení cílů výuky cizích jazyků. Ty spočívají mj. v tom, že se má stát př́íležitostí ke střetávání se s jiným/cizím, k prožívání rozdílů i shod, stát se př́iležitostí pro rozvoj

10 Jazyková identita nás determinuje ve vyjadřování, při artikulaci názorů, postojů, pocitů atd.,jinými slovy významným způsobem ovlivňuje realizaci komunikačních záměrů. Průcha (2004) uvádí v souvislosti s tímto fenoménem př́klad z oblasti vyjadřování emocí, v němž byly jednoznačně prokázány interkulturní rozdíly. Poukazuje na srovnávání, jakými způsoby př́íslušníci různých etnik a národů mohou komunikovat své emoční stavy v závislosti na tom, co jim umožňuje jejich typ jazyka, a určují kulturně dané komunikační normy v dané společnosti. 
interkulturní komunikační kompetence jako jejího hlavního cíle. I když je význam jazyka/jazyků pro vytváření a rozvoj identity nesporný, nejde zde o to, aby se žák v této situaci vzdal své vlastní identity nebo si „osvojil“ identitu jinou ${ }^{11}$. Jde o to, aby během výuky mohl rozpoznat, jak složité jsou mechanismy nejen mezi různými kulturami, ale i v rámci jedné kultury. Sílící uvědomování si toho, že lidé nevlastní pouze jednu jednodimenziální identitu, ale současně mohou přináležet vícero společenstvím, s nimiž se mohou identifikovat, je cílem potřebným, ale zároveň velmi obtížným v jeho dosahování (BurwitzMelzer, 2013, s. 40). Bredella (2002) při této př́ležitosti zmiňuje, že ve výuce cizích jazyků se:

jazyk a kultura navzájem od sebe oddělují, protože učící se jedinec vnímá cizí jazyk na pozadí své vlastní kultury. To vedlo často k pokusům tento rozkol mezi jazykem a kulturou odstranit. [...] Při vyučování a učení se cizím jazykům je nezbytné brát v úvahu překrývání a vzájemné prolínání mateřského a cizího jazyka i kultury, s čímž se jedinec může obtížně vyrovnávat. [...] Interkulturně orientovaná výuka cizích jazyků vnáší do povědomí mnohé kulturní rozdíly a zostřuje senzibilitu žáků pro ně. (s. 129-130)

\section{ad 2) Motivace a identita}

V souvislosti $\mathrm{s}$ motivací v procesu učení se cizím jazykům a s ní spojovaným fenoménem identity rozvinula Nortonová (2013) tzv. konstrukt investice (construct of investment), který se soustřed'uje na komplexní vztah mezi identitou žáka a jeho angažovaností při učení se (cizím) jazykům. Vychází přitom z přesvědčení, že pokud jedinec investuje do učení se jazyku či jazykům, činí tak s vědomím, že si osvojí širokou paletu symbolických (k nimž patř̌́ i jazyk) a materiálních zdrojů, které zvyšují jeho kulturní kapitál a sociální sílu. Mehlhornová (2013, s. 183) tento fenomén uvádí na příkladu své praxe jako poradkyně při učení se němčině jako druhému jazyku, v níž se často setkává s tím, že např̀ jedinci s ruštinou jako mateřským jazykem se cítí díky svému ruskému akcentu při používání němčiny značně stigmatizováni a intenzivně se snaží tento akcent odbourat či alespoň eliminovat, nebot' jej (často subjektivně) vnímají jako deficit v interakci s okolím, tedy s jinou kulturou. Identifikace s kulturou cílového jazyka jde tak ruku v ruce se silným přáním

11 Výsledky některých studií však poukazují na pravý opak, totiž že někteří jedinci/žáci dokonce touží změnit svoji vlastní identitu a přiblížit se identitě někoho jiného (např. Kramsch, 1997, s. 3). 
tento jazyk používat v gramatické a fonetické rovině co možná nejsprávněji a zároveň si osvojit co nejširší výrazový repertoár.

Pokud se naproti tomu jedinec s kulturou cílového jazyka nechce identifikovat (např. z důvodů různých předsudků vůči této kultuře), odráží se to často v nedostatečné motivaci při učení se tomuto jazyku (viz např. Dörnyei, 2003; Biel, 2007). Na tomto místě je však také třeba zmínit, že na vztah motivace a identity při učení se cizím jazykům lze pohlížet i z opačné strany: Pokud totiž není identita jedince dostatečně stabilizovaná, pak i učení se cizímu jazyku v sobě skrývá nebezpečí nejen nedostatečné motivace, ale i ohrožení identity jedince a z toho plynoucí strach, navenek projevený i jako odpor nebo nechut' k cizímu jazyku. ${ }^{12}$

\section{ad 3) Zaměření na žáka a identita}

V neposlední řadě je třeba říci, že otázky identity v kontextu učení se cizím jazykům úzce souvisejí také se současně akcentovaným zaměřením na žáka, nebot' procesy učení jsou výrazně determinovány „identitou žáka, který během svého kognitivního/intelektuálního vývoje prochází různými fázemi a stupni lingvistické kompetence" (Ahrens, 2013, s. 19). Identita každého jedince se projevuje v jeho individualitě, a to nejen v různé „kvalitě“ lingvistické a interkulturní komunikační kompetence, ale i v jeho jedinečném jazykovém repertoáru, což velmi úzce koreluje s oblastí předcházející i následující.

\section{ad 4) Individuální mnohojazyčnost a identita}

Se zřetelem k rozvoji zejména individuální mnohojazyčnosti v rámci pedagogické komunikace (Krumm, 2013) se jeví jako podnětné didakticky využívat jazykovou „expertnost“ jednotlivých žáků (jejich znalosti různých jazyků) a poskytnout jim př́ležitost sdělit svým spolužákům tyto znalosti, svůj vztah $\mathrm{k}$ jazykům a pohled na ně. To spoluutváŕí vhled do vztahu mezi rozvojem nejen osobní, ale i sociální identity, a podporuje rozvoj jazykového povědomí (language awareness, srov. Königs, 2013, s. 114) a kulturního povědomí (cultural awareness), stejně jako motivující interakce ve školní tř́ídě. Tímto

\footnotetext{
2 V souvislosti s institucionální/školní výukou cizích jazyků zde nalézáme paralely s Eriksonem a jeho vývojově pojatou teorii ego identity. V období adolescence (vývojové období mezi pubertou a ranou dospělostí, zpravidla od 11-13 do 21 let věku, viz Jandourek, 2001, s. 13) se v současnosti žáci učí jednomu až dvěma cizím jazykům. A právě v této době dochází k tzv. krizi identity, která se poté může odrazit i v jejich vztahu ke všemu „cizímu“, mj. i cizím jazykům či „cizím“ (jiným) kulturám.
} 
tématem se zabývá v jedné své studii např. Canagarajah (2004), který si stanovil za cíl blíže osvětlit vliv různých kultur na pedagogickou komunikaci a identifikovat tzv. bezpečná místa či chráněný prostor (safe house) pro jedince s různým kulturním a často i jazykovým původem, které můžeme vnímat jako př́ležitost pro podporu jejich vzdělávání s ohledem na jejich různé (odlišné) identity. Pedagogickou situací byl předmět akademického psaní, respondenty byli afroameričtí a tamilští studenti na Srí Lance, kteří si osvojovali akademickou angličtinu jako druhý jazyk.

Tento aspekt by měla $v$ mnohem větší míře reflektovat i běžná výuka cizích jazyků, jak ji známe $\mathrm{z}$ našeho kulturního kontextu. Mělo by se $\mathrm{v}$ ní lépe využívat možnosti poskytování výše zmíněného tzv. „chráněného prostoru“ pro explicitnější tematizování identity v rámci osvojování i užívání jazyka a tím způsobem přispívat k rozvoji pozitivního sebepojetí (sebekoncepce, self-concept) v cizím jazyce (Aguado, 2013, s. 16).

Nejen ve výuce cizích jazyků, ale i během jazykového poradenství lze při volbě vhodných metod a postupů umožnit žákům získat hlubší vhled do vlastního vztahu $\mathrm{k}$ jazyku či jazykům i do procesů jejich učení. Mohou přitom získat poznatky o svém individuálním vztahu mezi rozvojem identity a jazykem a lépe si uvědomit to, do jaké míry se chtějí aktivně na tomto rozvoji podílet a jaké silné či slabé stránky jsou spojeny s procesem učení se cizím jazykům i jejich užíváním. (srov. Hoffmann, 2013)

\subsection{Kidentitě ve výzkumu učení a vyučování cizích jazyků}

V aktuálních výzkumech identity se do popředí zájmu dostávají spíše určité aspekty/fragmenty či náhodnosti jako znaky konstrukce identity. A právě v tomto kontextu se mj. otevírá další prostor pro zkoumání jazyka a identity, konkrétně poté vztah mezi rozvojem identity a jazykem/jazyky, resp. jejich učením i vyučováním a identitou. $Z$ této perspektivy je kruciální konceptualizace konstruktu identity a precizní terminologické vymezení, jež jsou poté důležitými východisky pro operacionalizaci konkrétně zaměřeného výzkumu, v němž může být identita zkoumána $s$ akcentováním pohledu různých vědních disciplín, at' je to např. psychologie, sociologie, sociolingvistika, pragmalingvistika nebo pedagogika. Stejně tak je třeba zvážit, zda se výzkum bude zaměřovat spíše na učitele či žáka nebo jaké výukové situace jsou pro tematizování identity zvlášt' příhodné. ${ }^{13} \mathrm{~S}$ tím poté úzce souvisí

13 Podle Blellové (2013, s. 31) je to zejména oblast rozvoje řečové produkce i percepce, reálií nebo práce s literárním textem. 
i volba výzkumných metod, které se jeví pro daný záměr nejvhodnější, přičemž v obecné rovině jsou preferovány metody kvalitativního výzkumu. Osvědčuje se zde zejména biografický přístup s využitím metody jazykové biografie (např. Janíková, 2012, 2014). Upřednostňovány jsou otevřené a nestrukturované výzkumné plány, stejně jako případové studie, tedy rozsahem malé výzkumné vzorky, od nichž je získáváno velké množství informací. Zvlášt' respektovány jsou individuální životní dráhy (osudy) a interakce mezi účastníky výzkumu. Z př́ístupů kvalitativní analýzy dat převládá interpretativní fenomenologická analýza společně s diskurzivní (včetně konverzační) a narativní analýzou (srov. Hendl, 2008). Z pohledu lingvistických disciplín je tento výzkum realizován nejčastěji jako jazykově sociologický a sociolingvistický (Mehlhorn, 2013, s. 189), v posledních letech pak i jako interkulturně pragmatický (např. Auer \& Nekvapil, 2014; Tůma, 2014). V úvahu je třeba rovněž vzít aspekty, které byly nastíněny již výše. K zásadním patří fakt, že za stěžejní je při formování identity sice považován mateřský jazyk, ale i znalosti cizích jazyků včetně procesů jejich osvojování skrývají značný potenciál pro její další rozvoj. Je třeba si také uvědomit, že vztahy jazyka a identity jsou složité a mnohodimenzionální a implikují řadu typů identity. Připomeňme několik z nich: Jazyk nelze oddělit od kultury (kulturní identita), sociálních rolí (sociální identita ${ }^{14}$ ), v jejichž rámci probíhají interakce, v nichž jsou realizovány komunikační záměry jazykem, který se vyznačuje kulturními rozdíly (jazyková identita) ${ }^{15}$ aj. Podstatnou roli zde sehrává také současný přístup k výuce cizích jazyků, který se ve velké míře opírá o tzv. komunikační metodu (70. léta 20. století) a během dalších let byl obohacen o interkulturní aspekty. Pozornost je v něm zaměřena na osvojení jazyka v jeho komunikační funkci, přičemž hlavním cílem je rozvoj interkulturní komunikační kompetence při zohledňování nejen interlingvní, ale i interkulturní kontrastivity. I zde je obsažena identita nejen jedince, ale i identita různých kultur a etnik.

14 K prvním pokusům uchopit $\mathrm{v}$ českém výzkumu vztahy mezi sociální identitou a jazykem můžeme zařadit práce Hrdé, která se zaměřuje na češtinu jako cizí, resp. druhý jazyk v souvislosti s integračními tendencemi sociálně znevýhodněných skupin, tedy migrujících cizinců, $v$ kontextu jejich jazykové integrace do většinové společnosti a minimalizace možnosti jejich sociálního vyloučení (Hrdá, 2008), a výzkum opírající se o specifický pohled na významnou spojitost mezi interakcí komunikujících, jejich pragmatickou kompetencí a jejich sociální identitou (Hrdá \& Šíp, 2011).

15 Složitost vztahů mezi jazykem a kulturou činí rovněž jejich reciprocita, kdy jazyk a jazykový obraz světa, tzn. v jazyce obsažená interpretace reality a vidění světa, jsou jedněmi z faktorů, které vytváří kulturní rozdíly. 
Dle Meißnera (2013, s. 195-199) lze v souvislosti s identitou a jazykem, včetně identity $v$ rámci procesů učení se jazykům, nalézt v současné době následující výzkumné oblasti: a) konstrukce „Já“ a alterace, b) identita a jazyk v celoživotní perspektivě, c) kompetence a identita, d) identita a výuka jazyků, e) identita, okolí a jazyky migrantů.

a) „Já" a alterace

Pro současné výzkumy považuje Küster (2010, cit. podle Königse, 2013, s. 110) za relevantní fenomén tzv. ideálního Já, což mj. znamená jisté „vyladění" se s reálným Já, tedy potvrzení či korektura pomocí druhých (např. rodina, přátelé, kolegové v zaměstnání či příslušníci jiných kultur hovořící jinými jazyky) a vnímání jejich (cizího) úsudku. Tématem pro výzkum se zde může stát např. ukotvení „ideálního Já“ v interakci s cílovou nebo vlastní skupinou, stejně jako komunikace $\mathrm{v}$ různých jazycích. Jedná se zejména o následující kontexty: místo užívání cizích jazyků v rodné zemi s příslušníky vlastní kultury, v cizí zemi s heterokulturními partnery, přičemž je třeba vzít $\mathrm{v}$ úvahu jak osobní, tak sociální identitu. Zde se můžeme opírat o teorii jazyka, kterou formuloval Coseriu (1974, s. 60), podle níž je jazyk (dialog) primární základ a primární způsob vyjádření intersubjektivity, mluvení (ř̌č) je chápána jako konstituovaná sociální identita, která je určována intersubjektivitou a historicizmem (Kresic, 2006, s. 169). Coseriu chápe alteraci ve smyslu mluvení jako ostatní a mluvení pro ostatní. V jeho teorii silně vystupuje do popředí Maedova symbolickyinterakcionalistická teorie identity a Foucaultova teorie diskurzů. Z hlediska sociolingvistiky a pragmalingvistiky je alterace uchopena ve smyslu jazykového zapojení partnera v komunikaci s ohledem na vhodné používání různých a pro daný jazyk specifických vyjadřovacích prostředků. Předmětem výzkumu se rovněž může stát diatopický (např. dialekt), diastratický (sociolekt) nebo diafazický (styl) aspekt jazyka, které jedinec citlivěji vnímá až v pokročilejší fázi osvojování cizího jazyka, a jež mají svůj význam i při konstituování jazykové identity (Kresic, 2006, s. 171).

\section{b) Identita a jazyk v celoživotní perspektivě}

$\mathrm{V}$ pojetí identity jako dynamicky a v celoživotní perspektivě se měnícího fenoménu se nabízí zejména longitudinální biografický výzkum zaměřený např. na rozvoj jazykového povědomí, procesy učení se jazykům nebo na zkoumání vztahů mezi věkem a osvojováním, příp. užíváním jazyků v kontextu migrace tak, jak jej realizoval např. Krumm (2010). Faktor 
dlouhodobosti ve svém výzkumu identity akcentuje i Werlen (2002), který vychází z předpokladu, že jazyk se významně podílí na proměnách identity, umožňuje př́istup k jiným kulturám a otevírá možnost k rozvoji vlastní identity či popř. „dojití“ $k$ identitě nové, přičemž během delší životní etapy jedince může docházet $\mathrm{k}$ „prolínání“ identit. Ve svém biografickém výzkumu při využití metody jazykové biografie (data získávána pomocí narativního rozhovoru) Werlen (2002) mj. zjišttuje, že např. u migrantů (v jeho případě se jednalo o italské migranty druhé generace $v$ německojazyčné části Švýcarska) lze mnohdy identifikovat $\mathrm{v}$ souvislosti s jazyky tzv. dvojitou identitu. Tato oblast výzkumu koresponduje s tím, že zejména v průběhu 20. století značně zesílil společenský tlak na hledání a nalézání vlastní identity. Hledání vlastní identity se stalo osobním životním projektem a vyhledávanou hodnotou samo o sobě.

\section{c) Kompetence a identita}

Otázky identity jsou spjaty i s komunikační kompetencí, tedy s úrovní (či virtuozitou - viz výše) osvojení jazyka. I v obecné rovině platí, že to, co člověk umí/zná, má vliv na to, jak je přijímán či vnímán okolím, což se odráží i v jeho sebepojetí. I když jsou kompetence mnohdy mobilizovány vưlí jako vnitřní dispozicí osobnosti, která kontroluje chování jedince, aby bylo v souladu s interiorizovaným systémem hodnot a s racionálními perspektivami jednání, zároveň interagují s mnoha jinými faktory, jako je kulturní kontext, znalosti interkulturních a pragmatických aspektů komunikace i znalosti o vlastních procesech učení. To, co jedinec umí, má poté vliv na to, jak je okolím vnímán a jak vnímá sám sebe. Tuto oblast zkoumá např. Meißner (2012) ve svém šetření orientovaném na identitu s ohledem na jazykové kompetence žáka při učení se cizím jazykům.

\section{d) Identita a výuka jazyků}

Caspari (2003) poukazuje na to, že učitelé i žáci naplňují své sociální role a v jejich rámci mají určitá očekávání vzhledem k vlastnímu „Já“. Zde se nabízejí např́iklad (i gendrové) výzkumy k ozřejmění komplexu faktorů, jako je obraz jazyků, pedagogická interakce (viz výše např. Canagarajah, 2004) nebo interference mezi jednotlivými jazyky (více viz v úvodu této kapitoly). 


\section{e) Identita, prostředí a jazyky migrantů}

Zvláště v současné době - pod vlivem zejména politicky, sociálně a ekonomicky podmíněné dramaticky narůstající migrace - je velmi aktuální oblast didaktiky tzv. druhého jazyka ( $\mathrm{v}$ České republice se jedná o češtinu pro cizince, kteří chtějí nadále v této zemi žít; viz Hrdá \& Šíp, 2011). Jedinec/žák s migračním původem se setkává s novým/cizím jazykem a novou/cizí kulturou země, kde by chtěl úspěšně žít. Zde získávají status migranta, od kterého se očekává, že obé beze zbytku přijme. Setkáváme se však s př́ípady, v nichž takoví jedinci odmítají kulturu (někdy i jazyk) přijímající země a svoji identitu spojují se zemí svého původu (Meißner, 2013, s. 198) Tento nanejvýše delikátní problém vyvolává řadu otázek i v oblasti jazykové politiky, např. zda má být nabídnuta těmto jedincům výuka i jejich mateřských jazyků či jak jim vysvětlit, že pro jejich identitu není znalost jiného jazyka a respektování jiné kultury ohrožující (srov. Königs, 2013, s. 116-117). K obecným charakteristikám studií tohoto zaměření patří kvalitativní přístup, nebot' je zkoumáno to, jak jednotlivci a skupiny nahlížejí, chápou a interpretují svět pomocí jazyka.

Jak naznačují výše uvedené oblasti, nabízejí se tomuto oborovědidaktickému výzkumu zaměřenému na fenomén identity mnohá témata, $\mathrm{k}$ nimž lze přistupovat $\mathrm{z}$ různých perspektiv a s použitím různých metodologických př́ístupů.

\section{$5 \quad$ Jedno malé zamyšlení}

I když v posledních několika letech $\mathrm{v}$ odborném diskurzu k otázkám identity a učení se / osvojování si cizích jazyků a vyučování cizím jazykům převládá názor, že tyto dvě oblasti jsou prokazatelně v těsném vztahu a v měnící se moderní společnosti představují právě pro oborovědidaktický výzkum novou výzvu, neměly by se ztratit ze zřetele i jistě oprávněné kritické úvahy. Dosavadní zjištění získaná v rámci teoretického i empirického výzkumu poukazují na to, že výuka (cizích) jazyků může jedinci napomoci k rozpoznání vlastní identity a uvědomění si jejího dynamického charakteru. Nicméně někteří výzkumníci (např. Hufeisen, 2013, s. 80-81) doporučují při bádání $\mathrm{v}$ rámci tohoto výzkumného pole jistou ostražitost a zdrženlivost, a to přinejmenším ve dvou rovinách. $V$ obecné rovině se totiž institucionalizovaný proces vzdělávání, kterým jedinec prochází, významně podílí na utváření jeho povědomí o sobě samém, o společenství, v němž se nachází, ale i o světě, v němž žije. Výuka cizího jazyka se tak stává jedním ze střípků pestré mozaiky školních předmětů, v jejichž rámci je žákova identita více či méně záměrně 
ovlivňována a konstruována. Druhou rovinou je samotný učitel cizích jazyků, který sice v obecné rovině nese bezesporu velký díl zodpovědnosti za rozvoj jazykových znalostí a dovedností žáka i rozvoj celé jeho osobnosti, avšak v oblasti rozvoje jeho identity (vnímané jako nedílné součásti osobnosti jedince) je jeho úloha poněkud složitější. Je třeba totiž na ni v edukačním procesu - a tedy i ve výuce cizích jazyků - nahlížet jako na určitý znak, který nelze vtěsnat do kategorií, a pak hodnotit, nebo dokonce známkovat. Uvědomování si vlastní identity a její (případný) rozvoj jsou zpravidla dlouhými a velmi subtilními procesy, které jsou ovlivňovány i sebepojetím učitele cizích jazyků a které specifiky vyplývají z procesu zprostředkování cizích jazyků a kultur i jeho vlastní identitou (Hufeisen, 2013, s. 81). Tyto otázky a „nejistoty“ spojené s tím, do jaké míry, jakým způsobem, za jakých podmínek apod. se učitel cizích jazyků může seriózně podílet na rozvoji žákovy identity v edukačním procesu, se však na druhé straně stávají velkou výzvou pro další empirický výzkum v dané oblasti.

\section{Závěrem}

Pojem identita zaznamenal v posledních desetiletích zvýšený zájem badatelů $\mathrm{v}$ mnoha společenských a humanitních vědách; ve výzkumném poli některých $\mathrm{z}$ nich - $\mathrm{k}$ nimž je možné přiřadit i didaktiku cizích jazyků - se objevuje s výraznou razancí. Tento zájem má řadu důvodů. Jedním z nich je fakt, že v dnešním světě mají dynamicky se zvyšující migrace v rámci etnických, kulturních i jazykových hranic, narůstající individuální i společenská mnohojazyčnost, stejně jako transkulturalita jako vyústění interkulturality významné dopady na jedince a jeho vlastní identitu. $V$ těchto nových podmínkách jedinec začíná více přemýšlet o kulturním a sociálním prostředí, v němž se nachází a v němž hledá svoje místo, s nímž se chce (či musí) ztotožnit. Tyto skutečnosti poté vedou ke komplexnějšímu vnímání pojmu identity, $\mathrm{k}$ jehož hlavním atributům $\mathrm{v}$ současném pojetí patří zejména nestabilita, otevřenost, dynamičnost, jedinečnost a sociokulturní podmíněnost (srov. Janas, 2011). Zároveň dochází k diferencovanějšímu pohledu na vlastní konstrukt identity, což vede k rozlišování jejích různých typů (osobní, společenská/sociální, kulturní, profesní, jazyková atd.), což koresponduje s tím, že se jedinec ztotožňuje s více společenstvími či internalizovanými rolemi, do nichž během svého života v různých situacích vstupuje, má dvojí či trojí národní či etnickou identitu, zná více jazyků, přičemž právě jazyk je pro identitu konstitutivní. A to nejen při jejím utváření, v němž zásadní roli hraje jazyk mateřský/ 
první, ale i pro její rozvoj, během něhož sehrávají významnou roli cizí jazyky jako individuální bohatství jedince i jako společenský fenomén.

Identita v současném pojetí se tak i v důsledku výše nastíněných situací začíná poměrně razantně odrážet i v oblasti intencionálního i incidentálního učení se cizím jazykům, stejně jako při jejich vyučování, a to v teorii i empirii. $\mathrm{Z}$ hlediska teorie se ukazuje za přínosné uvědomování si potřeby těsnějšího propojování teorií osvojování (cizích) jazyků s různým pojetím identity a hledání jejich průniků s cílem vzájemného obohacení a umožnění hlubšího vhledu do složitých vztahů mezi jazykem a identitou. $V$ empirickém výzkumu procesů učení a vyučování cizích jazyků se nabízejí četné možnosti k dalšímu objasňování vztahu jazyka a identity, a to například v následujících oblastech: (profesní) identita učitele cizích jazyků, pedagogická komunikace ve výuce cizích jazyků ve třídě s větším počtem žáků-migrantů - př́íslušníků různých kultur, metodicko-didaktické postupy poskytující př́ležitost pro uvědomování si a rozvoj identity, sebepojetí a učení se cizím jazykům, rozvoj jazykového povědomí a jazykové kompetence, příp. kompetence k učení se cizím jazykům $v$ dlouhodobější perspektivě či nová témata $v$ oblasti jazykové identity $\mathrm{v}$ lingvisticky orientovaném výzkumu. $\mathrm{Z}$ hlediska metodologického se v této oblasti ukazuje jako velmi vhodný kvalitativní design. Rovněž edukační praxe, tedy výuka cizích jazyků jako předmět školní výuky, vykazuje jisté deficity v uchopování vztahů mezi jazykem a identitou, i když patří ke klíčovým oborům, které mohou (a mají) přinést významné impulsy pro konstrukci komplexní identity. Mimo jiné i proto, že mnohdy je pro učící se jedince obtížné hovořit z pozice jemu „nové identity“, ale při volbě odpovídajících metodicko-didaktických postupů jim může být poskytnuta př́ležitost nově rámovat svoji identitu, rozvíjet ji a získávat identitu alternativní a poté silnější.

I ve světle vědeckých pochybností a kritických úvah se domnívám, že fenomén identity a jazyka má své místo v současném i budoucím výzkumu procesů učení a vyučování cizích jazyků a jeho výsledky mohou přinést řadu nových impulzů pro teorii i praxi tak, jak to nastiňují mnohé zahraniční výzkumy.

\section{Literatura}

Aguado, K. (2010). Sozial-interaktionistische Ansätze. Deutsch als Fremd-und Zweitsprache. Ein internationales Handbuch, 2, 817-826. 
Aguado, K. (2013). Chunks, Imitation und Ko-Konstruktion: Wie nicht-kindliche Fremdsprachenlernende ihre L2-Identität(en) entwickeln können. In E. Burwitz-Melzer, F. G. Königs, \& C. Riemer (Eds.), Identität und Fremdsprachenlernen (s. 9-18). Tübingen: Narr Verlag.

Ahrens, R. (2013). Lernerorientierung und extrinsische Konditionierung im Fremdsprachenunterricht. In E. Burwitz-Melzer, F. G. Königs, \& C. Riemer (Eds.), Identität und Fremdsprachenlernen (s. 19-28). Tübingen: Narr Verlag.

Assmann, J. (2001). Kultura a pamět: písmo, vzpomínka a politická identita v rozvinutých kulturách starověku. Praha: Prostor.

Auer, P., \& Nekvapil, J. (2014). Jazyková interakce. Praha: Nakladatelství Lidové noviny.

Bačová, V. (1997). Identita v sociálnej psychológii. In J. Výrost \& I. Slaměník (Eds.), Sociální psychologie (s. 211-234). Praha: ISV.

Biel, K. (2007). Motivation und Fremdsprachenunterricht: Theorie, Forschung und Praxis. Saarbrücken: VDM Verlag Dr. Müller.

Blell, G. (2013).Sprach(en)lernen und Identität im Kontext eines literatur-und kulturdidaktischen Fremdsprachenunterrichts. In E. Burwitz-Melzer, E. Königs, \& C. Riemer (Eds.), Identität und Fremdsprachenlernen (s. 29-38). Tübingen: Narr Verlag.

Bredella, L. (2002). Zielsetzungen interkulturellen Fremdsprachenunterrichts. In L. Bredella (Ed.), Literarisches und Interkulturelles Verstehen (s. 125-152). Tübingen: Narr Verlag

Burwitz-Melzer, E. (2013). Sprache und Identität im Fremdsprachenunterricht. In E. BurwitzMelzer, F. G. Königs, \& C. Riemer (Eds.), Identität und Fremdsprachenlernen (s. 39-49). Tübingen: Narr Verlag.

Canagarajah, A. S. (2004). Subversive identities, pedagogical safe houses, and critical learning. In B. Norton \& K. Toohey (Eds.), Critical pedagogies and language learning (s. 116-137). Cambridge University Press: Cambridge.

Caspari, D. (2003). Fremdsprachenlehrerinnen und Fremdsprachenlehrer. Studien zu ihrem beruflichen Selbstverständnis. Tübingen: Narr Verlag.

Coseriu, E. (1974). Synchronie, Diachronie und Geschichte. Das Problem des Sprachwandels. München: Willhelm Fink.

Čermák, F. (2001). Jazyk a jazykověda. Praha: Karolinum.

Černý, J. (1998). Úvod do studia jazyka. Olomouc: Rubico.

Dörnyei, Z. (2003). Attitudes, orientations and motivations in language learning: Advances in theory, research, and applications. Oxford: Blackwell Publishing.

Erikson, E. H. (1996). Identität und Lebenszyklus. Frankfurt am Main: Suhrkamp.

Fleissner, K. (2014). 0 společenských vědách bez identity. E-LOGOS, 13, 2-13. Dostupné z http:// nb.vse.cz/kfil/elogos/science/fleissner14.pdf

Foucault, M. (1987). Slová a veci. Bratislava: Pravda.

Furdal, A. (2004). Jazyk a národní identita. Bohemistyka, 4(4), 241-245.

Hendl, J. (2008). Kvalitativní výzkum: základní teorie, metody a aplikace. Praha: Portál.

Hoffmann, S. (2013). Mündliche Kompetenz und Bewusstsein beim unterrichtlichen Fremdsprachenlernen. Philipps-Universität Marburg. Habilitationsschrift.

Hofstede, G., \& Hofstede, G. J. (2007). Kultury a organizace: software lidské mysli: spolupráce mezi kulturami a její důležitosti pro prežití. Praha: Linde.

Hrdá, M. (2008). Perspektiva češtiny jako nástroje integrační strategie. In D. Klapko (Ed.), Symposium sociální pedagogiky na PdF MU (s. 205-215). Brno: MSD. 
Hrdá, M., \& Šíp, R. (2011). Role pragmatické kompetence ve výuce češtiny jako cizího jazyka a utváření sociální identity. Pedagogická orientace, 21(4), 436-456.

Hufeisen, B. (2013). „Ich lerne (Fremd-)Sprachen, also bin ich?“ Sprachenlernen und Identität im Fremdsprachenunterricht. In E. Burwitz-Melzer, F. G. Königs, \& C. Riemer (Eds.), Identität und Fremdsprachenlernen (s. 80-83). Tübingen: Narr Verlag.

Janas, J. (2011). Jazyk a identita řecké minority v České republice. Dostupné z https://dspace. upce.cz/bitstream/10195/41991/3/JanasJ_JazykIdentita_L\%C5\%A0_2011.pdf.pdf

Jandourek, J. (2001). Sociologický slovník. Praha: Portál.

Janíková, V. (2012). Sensibilisierung für individuelle Mehrsprachigkeit. Lingua Viva, 8(15), 45-54.

Janíková, V. (2014). Ke kvalitativnímu výzkumu v didaktice cizích jazyků s př́kladem etnografického a biografického přístupu. In V. Janíková, M. Píšová, \& S. Hanušová (Eds.), Aktuální témata výzkumu učení a vyučování cizím jazykům (s. 7-26). Brno: Masarykova univerzita.

Kramsch, C. (1997). Culture and self in language learning. In R. Cherrington, L. Davcheva, \& I. Gazdov (Eds.), Teaching towards intercultural competence. Conference proceedings, Sofia 3.-5. October 1997 (s. 14-29). Bulgaria: The British Council.

Krappmann, L. (1993). Soziologische Dimensionen der Identität. Strukturelle Bedingungen für die Teilnahme an Interaktionsprozessen. Stuttgart: Klett-Cotta.

Kresic, M. (2006). Sprache, Sprechen und Identität. Studien zur sprachlich-medialen Konstruktion des Selbst. München: Iudicium.

Königs, F. G. (2013). Auf der Suche nach dem verlorenen Zusammenhang zwischen Identität und (Fremd-)Sprache(n) - eine unendliche Geschichte? In E. Burwitz-Melzer, F. G. Königs, \& C. Riemer (Eds.), Identität und Fremdsprachenlernen (s. 110-118). Tübingen: Narr Verlag.

Krashen, S. (1985). The input-hypothesis: Issues and implications. London: Longman.

Krumm, H.-J. (2003). „Mein Bauch ist italienisch ...“ Kinder sprechen über Sprachen. Zeitschrift für Interkulturellen Fremdsprachenunterricht, 8(2/3), 110-114.

Krumm, H. J. (2010). Mehrsprachigkeit in Sprachenporträts und Sprachenbiographien von Migrantinnen und Migranten. Arbeitskreis Deutsch als Fremdsprache (AkDaf) Rundbrief, 61, 16-24.

Krumm, H.-J. (2013). Identität und Mehrsprachigkeit. In E. Burwitz-Melzer, F. G. Königs, \& C. Riemer (Eds.), Identität und Fremdsprachenlernen (s. 119-128). Tübingen: Narr Verlag.

Küster, L. (2010). Identität und Identitätsbildung. In C. Surkamp (Ed.), Metzler Lexikon Fremdsprachendidaktik. Ansätze - Methoden - Grundbegriffe (s. 107-109). Stuttgart: Metzler.

Lantolf, J. P., \& Thorne, S. L. (2006). Sociocultural theory and second language learning. Dostupné z http://old.fltrp.com/download/07041802.pdf

Long, M. H. (1983). Native speaker/non-native speaker conversation and the negotiation of comprehensible input. Applied Linguistics, 4(2), 126-141.

Lukas, J., \& Švaříček, R. (2007). Reflexe problematiky zkoumání identity učitele. Příspěvek na XV. konferenci ČAPV, České Budějovice. Dostupné z http://www.jlukas.cz/doc/ pedagogicka/reflexe_problematiky_zkoumani_ucitele.pdf

Macek, P. (2003). Adolescence. Praha: Portál.

Mead, G. H. (1968). Geist, Identität und Gesellschaft. Frankfurt am Main: Surkamp.

Medgyes, P. (1994). The non-native teacher. Houndsmills: Macmillan. 
Meißner, F.-J. (2012). Konstruktion von Aufgaben zur Sprachlernkompetenz mit dem Referenzrahmen für plurale Ansätze (REPA). In C. Fäcke, H. Martinéz, \& F.-J. Meißner, (Eds.), Mehrsprachigkeit: Bildung - Kommunikation - Standards. Akten des 3. Bundeskongresses des GMF 2010 (s. 75-98). Stuttgart: Klett.

Meißner, F.-J. (2013). Sprachen kennen und können zwischen individuellen, nationalen und europäischen Identitätsangeboten. In E. Burwitz-Melzer, F. G. Königs, \& C. Riemer (Eds.), Identität und Fremdsprachenlernen (s. 194-207). Tübingen: Narr Verlag.

Mehlhorn, G. (2013). Identitätsangebote und Bedrohung der Identität russischsprachiger Lernender durch den schulischen Russischunterricht. In E. Burwitz-Melzer, F. G. Königs, \& C. Riemer (Eds.), Identität und Fremdsprachenlernen (s. 183-193). Tübingen: Narr Verlag.

Mlynář, J. (2015). Vztah paměti a identity v soudobé sociologii. In N. Maslowsky \& J. Šubrt, et al., Kolektivní pamět'. K teoretickým otázkám (s. 257-276). Praha: Karolinum.

Müller-Hartmann, A. (2013). „Ich habe mit ICC noch mehr Probleme als mit der Grammatik“ die Entwicklung professioneller Identität bei Fremsprachenlehrer/innen. In E. BurwitzMelzer, F. G. Königs, \& C. Riemer (Eds.), Identität und Fremdsprachenlernen, (s. 208-222). Tübingen: Narr.

Norton, B. (2013). Identity and language learning. In M. Byram \& A. Hu (Eds.), Routledge encyclopedia of language teaching and learning (s. 327-332). London: Routledge.

Průcha, J. (2004). Interkulturní psychologie. Praha: Portál.

Průcha, J. (2010). Interkulturní komunikace. Praha: Grada.

Riemer, C. (1997). Individuelle Unterschiede im Fremdsprachenerwerb. Eine Longitudinalstudie über die Wechselwirksamkeit ausgewählter Einflußfaktoren. Baltmannsweiler: Schneider Verlag Hohengehren.

Říčan, P. (1999). Cesta tam a pohled zpátky. Psychologie dnes, 11(15), 15.

Saville-Troike, M. (2006). Introducing second language acquisition. New York: Cambridge University Press.

Schmelter, L. (2013). Sprachenlernen und Identität im Fremdsprachenunterricht. In E. BurwitzMelzer, F. G. Königs, \& C. Riemer (Eds.), Identität und Fremdsprachenlernen (s. 269-276). Tübingen: Narr Verlag.

Schoormann, M., \& Schlak T. (2012). Sollte korrektives Feedback „maßgeschneidert“ werden? Zur Berücksichtigung kontextueller und individueller Faktoren bei der mündlichen Fehlerkorrektur im Zweit-/Fremdsprachenunterricht. Zeitschrift für Interkulturellen Fremdsprachenunterricht, 17(2), 173-190.

Skehan, P. (1998). A cognitive approach to language learning. Oxford: Oxford UP.

Stetsenko, A., \& Arievitch, I. (1997). Constructing and deconstructing the self: Comparing post-Vygotskian and discourse-based versions of social constructivism. Mind, Culture and activity, 4(3), 159-172.

Swain, M. (2005). The output hypothesis: Theory and research. In E. Hinkel (Ed.), Handbook of research in second language teaching and learning (s. 471-483). New York: Routledge.

Švaříček, R. (2007). Zkoumání konstrukce identity učitele. In R. Švaříček, \& K. Šed'ová, et al., Kvalitativní výzkum v pedagogických vědách (s. 335-355). Praha: Portál.

Tůma, F. (2014). Dialogismus a výzkum interakce ve třídě: přehledová studie (1990-2012). Pedagogika, 64(2), 177-199.

Vygotskij, L. S. (2004). Psychologie myšlení a řeči. Praha: Portál. 
Výrost, J., \& Slaměník, Z. (2008). Sociální psychologie. Praha: Grada.

Werlen, I. (2002). Sprachbiographien - Wie italienische Migrantinnen und Migranten der zweiten Generation in der deutschen Schweiz ihr Sprachleben sehen, Vals-Asla, 76, 57-77.

Wittgenstein, L. (1998). Filosofická zkoumání. Praha: Filosofia.

\section{Autorka}

Prof. PhDr. Věra Janíková, Ph.D., Masarykova univerzita, Pedagogická fakulta, Katedra německého jazyka a literatury, Poříčí 9, 60300 Brno, e-mail: janikova@ped.muni.cz

\section{Learning and teaching foreign languages, and identity}

Abstract: In the past sixty years, there has been a rapid development in research on processes of teaching and learning foreign languages. With similar intensity, new theories of foreign language acquisition have been created which investigate processes of both intentional and incidental language acquisition. These areas do not only reflect the latest findings from relevant neighbouring disciplines, but also the demands of the contemporary society on language training. This paper focuses on one of the areas, which is becoming, especially abroad, a widely discussed issue in the scholarly discourse on foreign language teaching methodology and research. This is the area of the complex and multidimensional relationship between language/languages and identity/identities of individuals in the context of teaching and learning of foreign languages. The paper opens with a brief glance at the constructs of identity and an outline of relevant theories of language learning and language acquisition which correspond to current concepts of identity. A general presentation of the relationships between language and identity follows. The next section presents those areas of FLT in which the construct of identity emerges with particular intensity. Last but not least, a research survey on the issue of relationships between language and identity in the context of teaching and learning of foreign languages is presented.

Keywords: learning and teaching foreign languages, identity, language identity, theory, research 